\title{
Study Demographic Driven on Indonesian Covid-19 Transmitted
}

\author{
Nuniek Nizmah Fajriyah ${ }^{1}$, Eko Mugiyanto ${ }^{2 *}$, Nur Izzah $^{3}$ \\ \{giyan77@gmail.com² \\ Nursing Department Faculty of Health Science University Muhammadiyah Pekajangan Pekalongan, \\ Central Java, Indonesian ${ }^{1,3}$ \\ Pharmacy Department Faculty Of Health Science University Muhammadiyah Pekajangan Pekalongan, \\ Central Java, Indonesian ${ }^{2}$
}

\begin{abstract}
Since the epidemic started in Wuhan, China, a new Chinese coronavirus, a relative of the SARS virus, has infected a million people worldwide. Until this article was published, more than 300000 people have infected the new Coronavirus. This research is descriptive study to show whether coronavirus disease spread is population density driven or not among Indonesian province. Indonesian population data retrieved from the Indonesian Central Agency on Statistics published in 2020, and Covid-19 patient data extracted from Indonesian Official Central for Disease Control for Covid-19 data. In this study, we found covid-19 spread intensively in dense population provinces like Jakarta and the province in java island than un dense province. Educational background seemingly did not contribute to a lower incidence of covid-19. Nevertheless, there is no link between the dense population and the covid-19 infected. Finally, the educational context did not seem to have led to a lower incidence of covid-19. Further study should be done to dig more profound the various factor that affects the spreading of Covid-19.
\end{abstract}

Keywords: Indonesian covid-19, dense population

\section{Introduction}

SARS coronavirus (SARSCoV) 2 is a new RNA coronavirus that belongs to the same family as SARSCoV and Middle East respiratory syndrome coronavirus (MERSCoV). SARS-CoV-2 was discovered in late 2019 as the origin of a pneumonia epidemic in Wuhan, from which it quickly spread across China, infecting more than 300,000 people [1], [2]. SARS-CoV-2 infection, like other coronaviruses, primarily causes flu-like symptoms, though severe lung damage has been reported in people of all ages, as well as acute respiratory distress syndrome (ARDS) and subsequent multiorgan failure in specific high-risk individuals, such as the elderly or those with multiple comorbidities, who are prone to severe acute respiratory failure [3]. The novel coronavirus spreads mostly through the nasal passages and uses the same SARS-CoV receptor, angiotensin-converting enzyme 2 (ACE2). The primary cause of transmission, which occurs predominantly by infected droplets, hands, or surfaces, is human-to-human aerosol transmission. By close interaction with mucous membranes, virus particles that are found in secretions from the respiratory system of an infected person infect others [4].

Destruction to the pulmonary interstitial arteriolar walls suggests that considering the virus's pathogenic impact, the inflammatory response plays a significant role in developing the disease [5]. Other common characteristics of critical COVID-19 patients, besides respiratory 
failure, include a sudden decrease in the patient's health status around two weeks after induction [6]. Today, implementing traditional healthcare-associated infections such as daily handwashing with soap and wearing a face mask are the most successful prevention techniques being implemented worldwide [7] and along with the implementation of social distancing steps, instructions for "stay in place," thorough testing, and touch tracing [8]. The Indonesian government has practiced those global recommendations through direct order by Indonesia President Joko Widodo, implemented in Government regulation No. 21/2020 [9].

In terms of health, urbanization is one of the most fundamental shifts that society is experiencing today and will face in the future decades [10]. Over half of the world's population already lives in cities; by 2050 , this proportion will have risen to over $70 \%$, with more than half of the urban population residing in cities with populations of more than 500,000 [11]. Indonesia's present population is expected to peak at 337.38 million by 2067, then fall in succeeding decades, according to current projections. Between 2000 and 2010, Indonesia's population grew at an annual rate of 1.49 percent on average. Indonesia's yearly growth rate is expected to improve by roughly 1.07 percent by 2020 , implying that the country's population is currently growing at a rate of about 2.73 million people per year [12]. Even though it is common to correlate population with disease spread, but limited studies demonstrated the association between transmitted diseases, in this case, covid-19, with a population density.

The first case identified in Indonesia is two Indonesian people living in Depok, which has a history of contact with Japanese people first believed to have suffered from the disease [13]. Following that, in Jakarta, the capital city, several covid-19 suspects spread rapidly with a large number of rates. It is general knowledge that dense urban areas, such as Jakarta, pose a health risk. Nonetheless, "density" is a broad term that encompasses a variety of aspects of the urban environment, each of which may have influenced the spread of COVID-19 in different ways. While it is difficult to draw definitive conclusions about why some areas were more affected than others at this stage of the crisis, there is a significant lack of correlation between population density, as defined and calculated in the policy and planning sectors, and rates of COVID-19 cases per capita in Jakarta and other Indonesian provinces. Here we study the correlation between density and covid-19 spread across Indonesia province.

\section{Method}

This is a descriptive study of covid-19 infected in Indonesia province. The Indonesian province population was retrieved from the Indonesian Central Agency on Statistics (BPS) published in 2020, and total number covid-19 patient data were extracted from the Indonesian Official Central for Disease Control for Covid-19 data accessed on September 30, 2020.

\section{Results and Discussions}

Density is a fascinating aspect that incorporates many urban society elements. In different forms, each of which may have influenced the COVID-19 outbreak. It is possible to clearly describe population density as the number of species per area or volume unit [14]. More than 300 ethnic and linguistic groups make up Indonesia's population, with Javanese constituting the majority and most powerful political force. These figures are from the previous national census in 2000. The Indonesian population's ages still present a fascinating story. In the year 2000, 27.3 


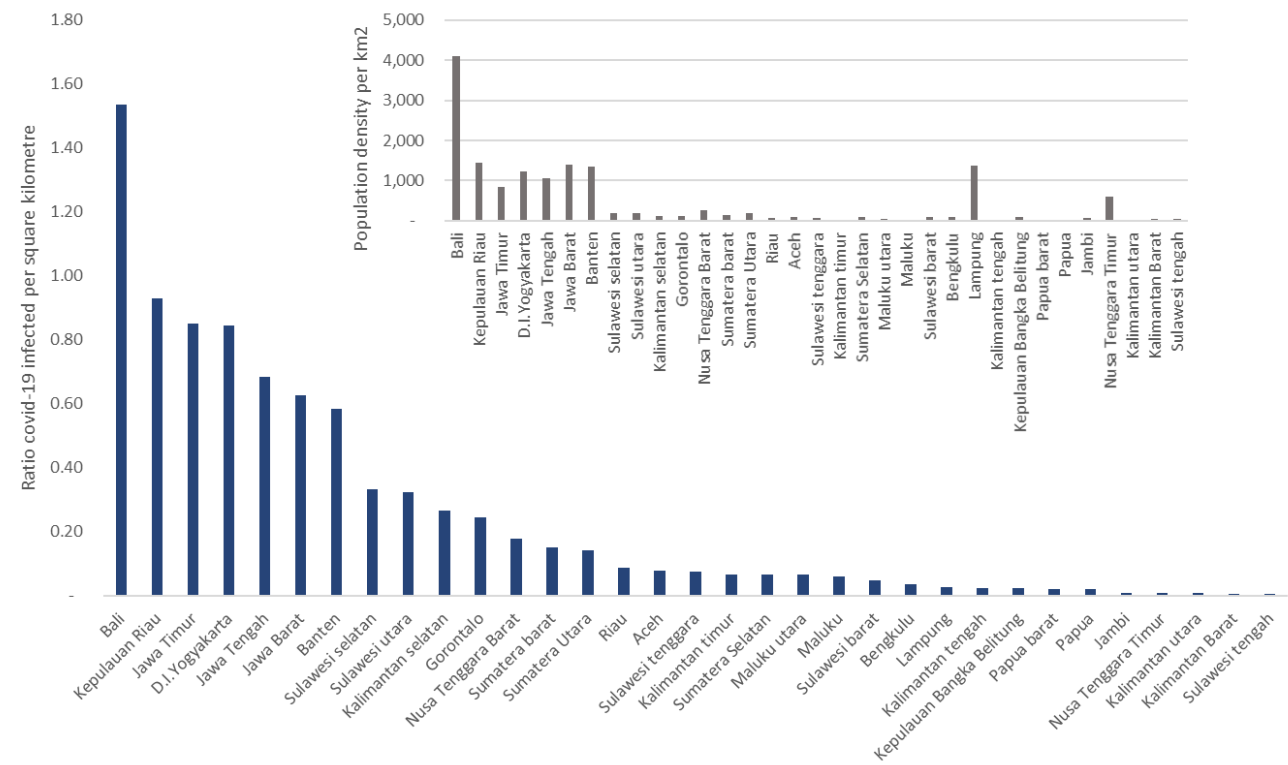

Fig. 2. Covid-19 Infected patient per square kilometer in Indonesian province ranked base on higher to lower population density. DKI Jakarta with 111 covid-19 infected per square kilometer was excluded. Bali and others province in java island have higher covid-19 infected than other provinces. Insert, population density per square kilometer.

Over 1 billion students are at risk of falling behind as a result of school closures targeted at controlling the spread of COVID-19. In Indonesia, the Ministry of National Education is in charge of education. Six years of primary education and three years of junior high school are required. After optional pre-school playgroups, which may begin in a child's third year, the primary stage continues. Higher education associated with intellectualism will, to some extent, increase the likelihood to get a proper job, and eventually, there is a link with the economic situation, health, and hygiene-related knowledge [16]. Although, in several nations, growing pressure has been placed on them since the 1980s. Higher education leads directly to national economic regeneration and growth, too. However, Indonesian covid-19 transmitted shown no correlation between education level and the number of covid-19 infected show in Figure 3. Furthermore, a similar result has been shown when we correlate between the pauper number and covid-19 infected show in Figure 4. Certain density factors, such as the high number of individuals sharing living facilities or the high number of workers coming into contact at work, have contributed to the spread of COVID-19. Nonetheless, it is not connected with COVID-19 infection, as determined by the average number of individuals per square kilometer density. 


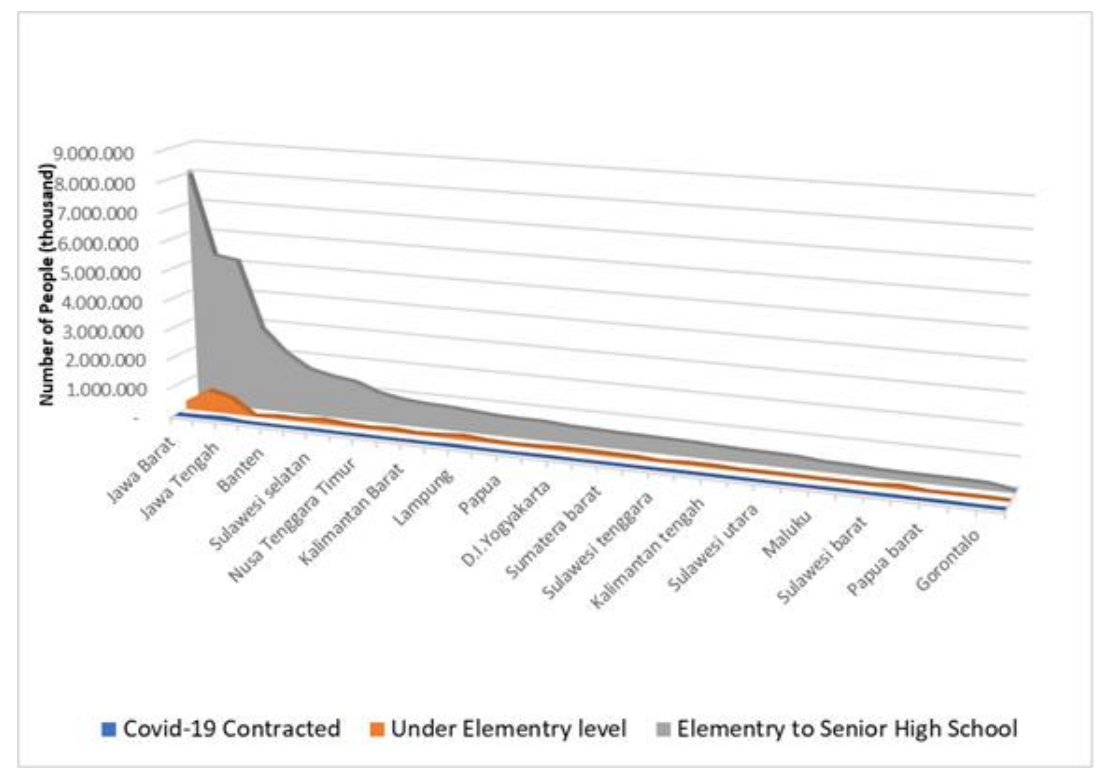

Fig. 3. Education level against covid-19 infected.

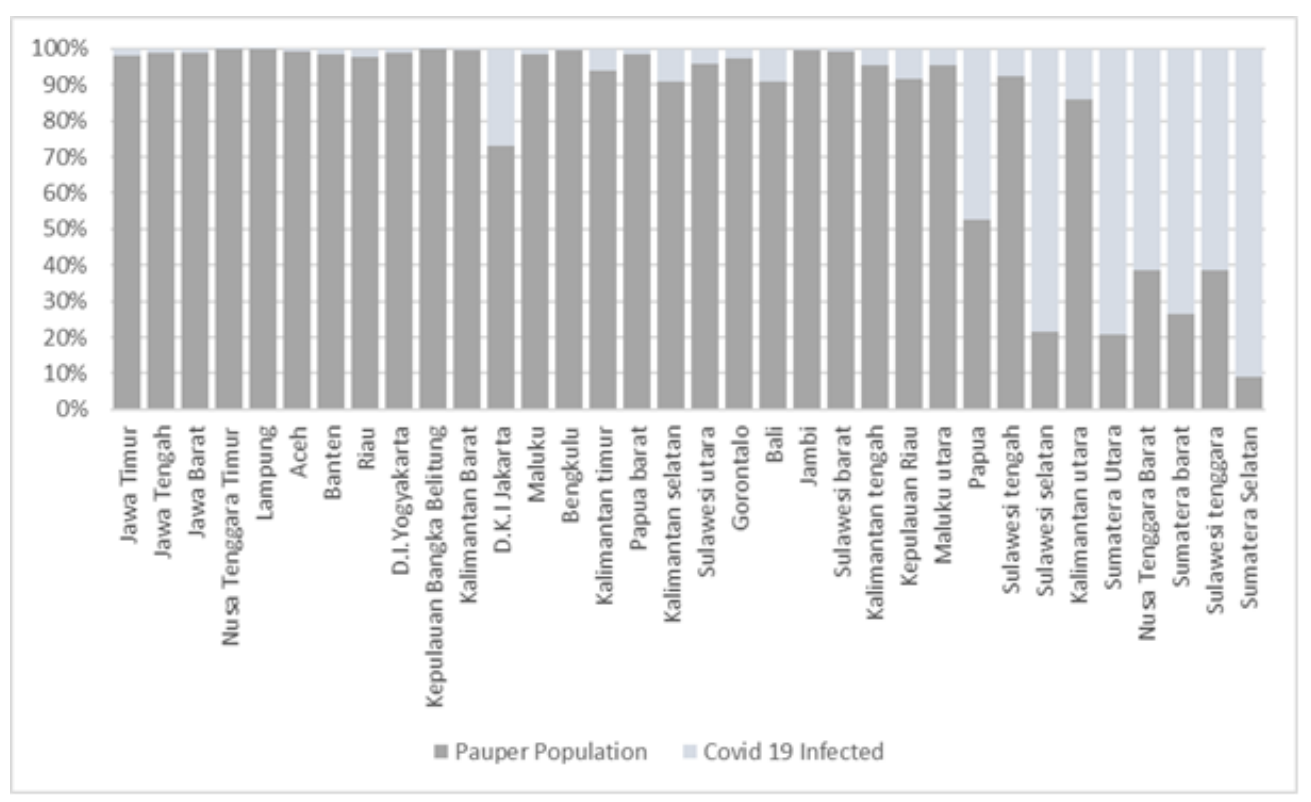

Fig. 4. The ratio between Pauper Population that infected with covid-19 among the Indonesian province. 


\section{Conclusion}

Covid-19 spread intensively in dense population provinces like Jakarta and the province in java island than un dense province. However, there is no correlation between dense population and covid-19 infected. The last is educational background seemingly did not contribute to a lower incidence of covid-19.

\section{Acknowledgement}

Thank you to the Department of Research, Community Service, and Publication of The University of Muhammadiyah Pekajangan Pekalongan Indonesia for supporting this study.

\section{References}

[1] Remuzzi A, Remuzzi G. COVID-19 and Italy: what next? (1474-547X (Electronic)).

[2] Holshue ML, DeBolt C, Lindquist S, Lofy KH, Wiesman J, Bruce H, et al. First Case of 2019 Novel Coronavirus in the United States. (1533-4406 (Electronic).

[3] Wu D, Wu T, Liu Q, Yang Z. The SARS-CoV-2 outbreak: What we know. (1878-3511 (Electronic).

[4] Adhikari SP, Meng S, Wu YJ, Mao YP, Ye RX, Wang QZ, et al. Epidemiology, causes, clinical manifestation and diagnosis, prevention and control of coronavirus disease (COVID-19) during the early outbreak period: a scoping review. (2049-9957 (Electronic)).

[5] Li G, Fan Y, Lai Y, Han T, Li Z, Zhou P, et al. Coronavirus infections and immune responses. Journal of Medical Virology. 2020;92(4):424-32.

[6] Zhang W, Zhao Y, Zhang F, Wang Q, Li T, Liu Z, et al. The use of anti-inflammatory drugs in the treatment of people with severe coronavirus disease 2019 (COVID-19): The Perspectives of clinical immunologists from China. Clinical Immunology. 2020; 214:108393.

[7] Cheng VC-C, Wong S-C, Chuang VW-M, So SY-C, Chen JH-K, Sridhar S, et al. The role of community-wide wearing of face mask for control of coronavirus disease 2019 (COVID-19) epidemic due to SARS-CoV-2. Journal of Infection. 2020;81(1):107-14.

[8] Matrajt L, Leung T. Evaluating the effectiveness of social distancing interventions against COVID19. medRxiv. 2020:2020.03.27.20044891.

[9] Anonim. The Jakarta Post. 2020(April 3, 2020).

[10] Adli M, Berger M, Brakemeier E-L, Engel L, Fingerhut J, Hehl R, et al. Neurourbanism - A joint methodological approach between urban planning and neurosciences. 2016; 13:70-8.

[11] Gruebner O, Rapp MA, Adli M, Kluge U, Galea S, Heinz A. Cities and Mental Health. Dtsch Arztebl Int. 2017;114(8):121-7.

[12] Anonim. Indonesia Population 2020 (Live). 2020.

[13] Anonim. Kasus Covid-19 Pertama, Masyarakat Jangan Panik.

[14] McArdle BH. Population Density. In: Levin SA, editor. Encyclopedia of Biodiversity. New York: Elsevier; 2001. p. 745-58.

[15] Anonim. Badan Pusat Statistik. 2020.

[16] Harvey L. New Realities: The Relationship Between Higher Education and Employment. Tertiary Education and Management Kluwer Academic Publishers. 2000;6: 3-17, 2000. 